all aerobic and anaerobic retting organisms are spore. formers.

From two different rets a spore-bearing aerobic bacillus was isolated in pure culture; this produced soft rot in potato under laboratory conditions. The morphology and reactions-formation of acid and acetoin, but no gas, from dextrose, rapid liquefaction of gelatin, digestion of milk, and strong diastatic power-of the two cultures were identical and conformed with those of $B$. subtilis. Their identity with this organism was confirmed by Dr. T. Gibson of Edinburgh, to whom subcultures were sent.

Testing the ability of a pure culture to ret flax is rendered difficult by the fact that the flax used as a substrate may be appreciably altered in character if it is sterilized by heat. To obviate this difficulty an enzyme powder, capable of acting in the presence of an antiseptic which inhibits bacterial growth, was prepared from each of the two strains of $B$. subtilis by the following method, which is similar to that described by Dox ${ }^{2}$.

A mass growth was obtained by seeding the surface of potato-mush agar sloped in ten 1-litre bottles. After incubation for two days at $30^{\circ} \mathrm{C}$., the growth was washed off with water and the aqueous suspension was filtered through a Buchner funnel. The residue on the filter paper was ground in a large volume of acetone and left immersed for ten minutes. The acetone was filtered off at the pump and the residue was similarly treated, first with acetone for two minutes and finally with other for three minutes. The residue after filtration was dried in a thin layer at $37^{\circ} \mathrm{C}$. for two to three hours, and was then ground to a fine greyish-yellow powder which was tested as follows :

(1) $0.2 \mathrm{gm}$. of the powder was ground with $5 \mathrm{ml}$. of distilled water and the suspension was transferred to a test tube. Several thin disks of freshly cut potato (approximately $1 \mathrm{~cm}$. in diameter and $1 \mathrm{~mm}$. in thickness), and $0 \cdot 2 \mathrm{ml}$. of toluene, were added to the suspension, which was thoroughly shaken. A control tube without the enzyme powder was prepared at the same time and both tubes were incubated at $30^{\circ} \mathrm{C}$. When examined after 18 hours, the disks of potato in the enzyme preparation showed complete soft rot, disintegrating easily when manipulated with a stiff wire. Disks in the control tube were unaltered.

(2) Flax stems were cut into uniform lengths of aboat 4 in., and were packed tightly into a glass cylinder about 1 in. in diameter. A suspension contrining $2 \cdot 5-3 \mathrm{gm}$. of the enzyme powder and $2 \mathrm{ml}$. of toluene in $50 \mathrm{ml}$. of distilled water was poured into the cylinder until the flax was completely immersed. A control cylinder without the enzyme powder was prepared in the same way, and both cylinders were incubated at $30^{\circ} \mathrm{C}$. Progress of retting was followed at intervals by means of the "loose core' test, and a small quantity of toluene was added daily to each cylinder. The flax immersed in the enzyme preparation was completely retted in three days, the flax in the control cylinder being unchanged.

These experiments show that $B$. sabtilis produces enzymes which rot potato and ret flax. The fact that tha process of retting in tainks on a large scale is accompanied by the growth in large numbers of spore-forming bacteria which produce soft rot of potato suggests that they may also be largely responsible for tha retting. It may be noted that ability of spore-forming bacteria to eause soft rot of potato, which Dowson ${ }^{3}$ recorded for B. polymyxa, is certainly not, under laboratory conditions, confined to that species.

L. A. Arlew.

Water Pollution Research Laboratory, Langley Road, Watford, Herts.

${ }^{1}$ Ruschmann, F., J. Text. Inst., 15, T61 and 104 (1924).

2 Dox, A. W., U.S. Dept. Agric. Bur. Anim. Ind., Bull. 120 (1910). ${ }^{3}$ Dówson, W. J., Nature, 152, 331 (1943).

\section{Reported Asymmetric Synthesis of Santonin}

THE announcement that santonin containing approximately 93 per cent of the lcevo-rotatory variety (naturally occurring santonin is lcevo-rotatory) has been obtained by Paranjape, Phalnikar, Bhide and Nargund ${ }^{1}$ during the synthesis of santonin without apparently any asymmetric influence at any stage of the synthesis is of unusual interest. The realiza. tion of such a result cannot be excluded on the evidence given. On the other hand, it is contrary to all analogous experimental results so far recorded that methylation of an externally compensated and optically inactive compound should proceed at different rates on the loevo- and dextro-constituents of the externally compensated substance even when the asymmetric carbon atom is involved. It is possible, however, to conceive cases when a difference in reaction velocities of the loevo- and dextro-varieties of an externally compensated compound may be realized.

So far as present conditions permit, it would be useful if as large a number as possible of experienced investigators should repeat the methylation of 2 -formylcyclohexanone under various conditions, and determine whether or not the resulting 2-methyl-2formylcyclohexanone is or is not optically active. If any positive evidence is obtained the statistical analysis of the results would be interesting.

Charles $\mathrm{S}$. Gibson.

Chemistry Department,

Guy's Hospital Medical School,

(University of London),

London, S.E.1. Jan. 30 .

${ }^{1}$ Natere, 153, 141 (1944).

\section{Microbiological Assay of Riboflavine}

Prof. R. H. Horkins ${ }^{1}$ has added to Dr. Barton Wright's and Mr. Booth's ${ }^{2}$ reply to the comments made by Happold ${ }^{3}$ on the microbiological technique for the assay of riboflavine and has ineluded a criticism of the work published by us ${ }^{4}$. Both communications concentrate on the point made by us regarding the amount of calcium.in the medium, while ignoring other points of criticism which we made. Barton Wright and Booth state that the calcium effect is due to buffer action, this being incorrect, while Hopkins, relying on the papers of Holt, La Mer and Chown ${ }^{5}$ on calcification in bone and on the solubility product of $\mathrm{Ca}_{3}\left(\mathrm{PO}_{4}\right)_{2}$ in water or in serum, states that the calcium concentration could not be influenced appreeiably by added calcium chloride at $p \mathrm{H} 6 \cdot 6-6 \cdot 8$. It should be mentioned that Holt et al. state that the solubility product is affected enormously by the presence of other salts and that a co plex solution of amino-acids is very different from serum (protected by these workers against bacterial proteolysis). They also state "the precipitation of tertiary calcium 